\title{
Potential of entomopathogenic nematodes of the genus Heterorbabditis for the control of Stomoxys calcitrans (Diptera: Muscidae)
}

\author{
Potencial de nematoides entomopatogênicos do gênero Heterorhabditis para o controle de \\ Stomoxys calcitrans (Diptera: Muscidae) \\ Luís Carlos de Souza Rodrigues Leal ${ }^{1 *}$; Caio Márcio de Oliveira Monteiro²; Alessandra Ésther de Mendonça3; \\ Vânia Rita Elias Pinheiro Bittencourt ${ }^{4}$; Avelino José Bittencourt ${ }^{5}$
}

\footnotetext{
${ }^{1}$ Programa de Pós-graduação em Ciências Veterinárias - CPGCV, Universidade Federal Rural do Rio de Janeiro - UFRRJ, Seropédica, RJ, Brasil

${ }^{2}$ Instituto de Patologia Tropical e Saúde Pública, Universidade Federal de Goiás - UFG, Goiânia, GO, Brasil

${ }^{3}$ Laboratório de Parasitologia Animal, Embrapa Gado de Leite, Juiz de Fora, MG, Brasil

${ }^{4}$ Departamento de Parasitologia Animal, Universidade Federal Rural do Rio de Janeiro - UFRRJ, Seropédica, RJ, Brasil

${ }^{5}$ Departamento de Medicina e Cirurgia Veterinária, Instituto de Veterinária, Universidade Federal Rural do Rio de Janeiro - UFRRJ, Seropédica, RJ, Brasil
}

Received July 10, 2017

Accepted September 28, 2017

\begin{abstract}
The present study verified the pathogenic potential of entomopathogenic nematodes (EPNs) of the genus Heterorhabditis (Heterorhabditis bacteriophora, isolate HP88 and Heterorhabditis baujardi isolate LPP7) to immature stages of Stomoxys calcitrans in the laboratory. All EPN concentrations of the H. bacteriophora HP88 strain caused mean larval mortality greater than $90 \%$ after four days. Higher concentrations of the H. baujardi LPP7 isolate ( $\geq 50 \mathrm{EPN} / / \mathrm{larva}$ ) eliminated more than $70 \%$ of larvae after six days with the concentration $200 \mathrm{EPNs} /$ larva reaching mortality levels of $93.3 \%$. The larval mortality at all concentrations of EPNs $(25,50,100,150$, and $200 \mathrm{EPN} s /$ larva) for both strains was significant $(\mathrm{p}<0.05)$ when compared to the respective control groups. Concentrations of H. bacteriophora HP88 yielded an LC50 of 0.36 EPN/larva and LC90 of 29.1; while H. baujardi LPP7 yielded an LC50 of 39.85 and LC90 of 239.18. H. bacteriophora HP88 provided greater inhibition of the emergence of adults when compared to the response obtained with H. baujardi LPP7. EPNs did not cause considerable mortality when applied directly to pupae. The set of observed results suggests that the EPNs of the genus Heterorhabditis, isolates HP88 and LPP7, are a promising alternative in the control of the stable fly.
\end{abstract}

Keywords: Stable fly, diptera, biological control, Heterorhabditis bacteriophora HP88, Heterorhabditis baujardi LPP7.

\section{Resumo}

O presente estudo verificou o potencial patogênico de nematoides (NEP) do gênero Heterorhabditis (H. bacteriophora - isolado HP88 e H. baujardi - isolado LPP7) para estágios imaturos de Stomoxys calcitrans em laboratório. Todas as concentraçôes de NEPs da cepa HP88 causaram mortalidade larval média maior que $90 \%$ após quatro dias. Concentraçôes mais elevadas da cepa LPP7 ( $\geq 50 \mathrm{NEPs/larva)} \mathrm{eliminaram} \mathrm{mais} \mathrm{de} \mathrm{70 \%} \mathrm{após} \mathrm{seis} \mathrm{dias,} \mathrm{com} \mathrm{a} \mathrm{concentração} 200 \mathrm{NEPs/larva}$ atingindo níveis de 93,3\%. A mortalidade larval em todas as concentraçóes de NEPs (25, 50, 100, 150, and $200 \mathrm{NEPs/larva)}$ para ambas as cepas foi significativa $(\mathrm{p}<0,05)$, quando comparadas aos respectivos grupos controle. Concentraçôes de H. bacteriophora HP88 obtiveram LC50 de 0,36 NEP/larva e LC90 de 29,1; enquanto H. baujardi LPP7 obteve LC50 de 39,85 e LC90 de 239,18. O isolado H. bacteriophora HP88 propiciou maior inibição da emergência de adultos, quando comparado à resposta obtida com $H$. baujardi LPP7. NEPs não provocaram mortalidade considerável quando aplicados diretamente sobre pupas. O conjunto de resultados observados indica os nematoides entomopatogênicos do gênero Heterorhabditis (estirpes HP88 e LPP7) como uma alternativa promissora no controle da mosca dos estábulos.

Palavras-chave: Mosca dos estábulos, diptera, controle biológico, Heterorhabditis bacteriophora HP88, Heterorhabditis baujardi LPP7.

\footnotetext{
*Corresponding author: Luís Carlos de Souza Rodrigues Leal. Universidade Federal Rural do Rio de Janeiro - UFRRJ, BR 465, Km 7, CEP 23890-000, Seropédica, RJ, Brasil. e-mail: mark.eraj@gmail.com
} 


\section{Introduction}

Stomoxys calcitrans, a hematophagous Diptera known as "stable fly", performs its growth in organic matter - development of the immature stages occurs mainly in animal feces associated with decomposing vegetable matter (COOK et al., 1999). After hatching, the larvae move deeper into organic matter for feeding and protection, requiring two weeks to reach the pupal stage (MELLO, 1989). According to Taylor et al. (2012), this fly is present in several regions of the world, including temperate climates, which, in certain circumstances, offer conditions for its development during only some months of the year, yet the fly can still cause considerable damages.

Taylor et al. (2012) indicated that annual losses in the United States reached 2,221 billion dollars. In Brazil, Grisi et al. (2014) estimated losses at US\$335.5 million. Evaluating the effect of S. calcitrans parasitism on cattle, Campbell et al. (1987) found that 35 flies per front leg were sufficient to cause losses of $12 \%$ in feed conversion and $20 \%$ in weight gain. The hematophagous habit and interrupted feeding, as well as the painful biting of the stable fly (BITTENCOURT, 2012), lead to defensive movements of the host to fend off the flies, which then land on another susceptible animal, thus being able to transfer pathogen-infected blood remaining in its mouthparts, facilitating the transmission of several pathogenic microorganisms (BALDACCHINO et al., 2013).

One class of agents with potential for biological control of the stable fly is the entomopathogenic nematodes ("EPNs"), which are obligatory parasites of insects and have a wide geographical distribution. EPNs of the genus Steinernema and Heterorhabditis are associated with symbiotic bacteria of the genus Xenorhabdus and Photorhabdus, respectively (BOEMARE et al., 1993). They search for and locate their hosts by products of excretion, $\mathrm{CO}_{2}$ levels and temperature gradients. When a host is located, they penetrate through natural openings (mouth, anus and spiracles) or actively penetrate through the cuticle, as in the case of Heterorhabditis sp. Inside the host, they migrate to the hemocoel (KAYA \& GAUGLER, 1993) where their symbiotic bacteria release toxins that kill the insect (HAZIR et al., 2003). The infective juveniles (IJ) then ingest decomposed tissues and the bacteria inside the host as they develop into adults. These nematodes can complete two to three generations inside the insect until nutrients are depleted, at which point the IJ (= J3) retain the bacteria and leave the dead insect to seek a new host in the environment (DOLINSKI et al., 2006).

EPNs have several characteristics making them desirable as control agents: they are highly virulent, easily cultivated in vitro, possess a large array of hosts, are highly specific to arthropods, are mobile and have high reproductive potential (KAYA \& GAUGLER, 1993). Currently, these nematodes are already used commercially for the control of agricultural pests in different regions of the planet (GEORGIS \& MANWEILER, 1994).

In relation to parasites of veterinary importance, most studies have used EPNs for control of ticks (SAMISH et al., 2008; MONTEIRO et al., 2010; SILVA et al., 2012; MONTEIRO, 2014) with few existing studies on the potential of these agents for control of flies. Notable exceptions include studies by Geden et al. (1986) and Taylor et al. (1998) with Musca domestica (Diptera: Muscidae) and Mahmoud et al. (2007) and Pierce (2012) with S. calcitrans.
The objective of the present study was to evaluate the pathogenic potential of the nematodes Heterorhabditis bacteriophora, and Heterorhabditis baujardi to immature Stomoxys calcitrans under laboratory conditions.

\section{Materials and Methods}

\section{Location of experiment}

The bioassays were conducted at the Research Laboratory of Hematophagous Diptera located at the Station for Parasitological Research W. O. Neitz (EPPWON), Veterinary Institute, Federal Rural University of Rio de Janeiro (UFRRJ), Brazil.

\section{Obtaining larvae of S. calcitrans}

The capture of adult $S$. calcitrans was carried out in cattle at the Veterinary Hospital of UFRRJ using an entomological net. Flies were stored in plastic transport cages $(15 \times 15 \times 20 \mathrm{~cm})$ and identified in a laboratory according to Furman \& Catts (1982). For the rearing of $S$. calcitrans under laboratory conditions, cages of plastic material measuring 60x40x50 cm were used (MORAES, 2007). Adult rearing cages and larval development media were kept in a climatized chamber (B.O.D.) at $27 \pm 1^{\circ} \mathrm{C}$ and $70-80 \%$ relative humidity $(\mathrm{RH})$. Bovine blood was transferred to a beaker, heated in a water bath (approximately $37^{\circ} \mathrm{C}$ ) to simulate the body temperature of the parasitized animal (MELLO, 1989), and supplied to the flies on a gauze pad twice a day. For the maintenance of larvae, modified Christmas larval rearing medium (CHRISTMAS, 1970) composed of sugar cane (66 g), wheat bran (25 g), meat meal (8 g), sodium bicarbonate $(1 \mathrm{~g})$ and distilled water $(127 \mathrm{~mL})$, was used.

\section{Obtaining and maintaining nematodes}

The nematodes $H$. bacteriophora strain HP88, and $H$. baujardi strain LPP7, were obtained from the Parasitology Laboratory at EMBRAPA Dairy Cattle, Juiz de Fora, Minas Gerais, Brazil. The nematodes were maintained in cell culture flasks ( $40 \mathrm{~mL}$ capacity) containing $20 \mathrm{~mL}$ of aqueous suspension with EPNs and were quantified by counting 10 aliquots of $10 \mu \mathrm{L}$. In each aliquot $(10 \mu \mathrm{L})$, the viable larvae were counted, and then the mean number of infective juveniles (IJ) was calculated per sample. From this mean, the suspensions were adjusted, by adding or removing distilled water from the bottles (MONTEIRO, 2014).

\section{Exposure of larvae and pupae of S. calcitrans to nematodes}

To perform the larval susceptibility test for each nematode species, the experimental unit consisted of five eight-day-old larvae placed in a Petri dish $(9 \mathrm{~cm}$ in diameter) lined with two sheets of filter paper in the lower part. To each plate, $2 \mathrm{~mL}$ of aqueous suspension of nematodes at the concentration of either 125, 250, 500, 750 or $1000 \mathrm{EPN} /$ /Petri dish (each concentration = one treatment) were added. Thus, the concentrations per larva 
were 25, 50, 100, 150 and 200 EPNs. In the control groups, $2 \mathrm{~mL}$ of distilled water (nematode-free) were added to the plates with five $S$. calcitrans larvae. The Petri dishes were then sealed with PARAFILM $^{\oplus}$ to prevent the escape of $S$. calcitrans larvae and stored in a climatized chamber at $27 \pm 1^{\circ} \mathrm{C}$ and $70-80 \%$ RH. Mortality of larvae was observed daily up to the 10 th day after exposure. After this period, the observations were continued to evaluate the possible formation of pupae and adult emergence.

The evaluation of the effect of EPNs on pupae was conducted in a similar way to the bioassays involving larvae; the experimental unit consisted of five pupae with three days of formation, and EPN concentrations per pupa were 100, 150 and 200 EPNs. This segment of the study was performed only with EPNs of the species $H$. bacteriophora HP88, and the pupae were followed for up to 12 days to verify the emergence of adults. Six replicates were performed per treatment in both experiments.

White traps Dead S. calcitrans larvae were deposited in White traps (WHITE, 1927) according to each treatment for recovery of infective juveniles and confirmation of death due to infection by EPNs.

\section{Statistical analysis}

For statistical analysis, the software Biostat, version 5.0, was used. The values for mortality means in each treatment were analyzed by ANOVA and Tukey's test $(p<0.05)$. In the case of non-normal distribution, the parameters were compared by Kruskal-Wallis and Student-Newman-Keuls tests $(\mathrm{p}<0.05)$. Determination of LC50 and LC90 was made using probit analysis on mortality data, and obtained together with $95 \%$ confidence upper and lower limits (FINNEY, 1952).

\section{Results and Discussion}

\section{S. calcitrans larval viability}

The usage of young $S$. calcitrans larvae in experiments carries two main risks: high mortality (control and treated groups) caused by the manipulation of larvae that are still fragile (MORAES, 2007) and mortality caused by lack of nutritional reserves in young larvae (L1 and L2). The latter is a particular risk in experiments where no development medium is provided in Petri dishes since $S$. calcitrans larvae require organic matter to feed and are dependent on this medium for protection from light and dryness. For this reason, in studies using freshly hatched $S$. calcitrans larvae, it is not recommended to adapt the methodology used by Senna-Nunes et al. (2002) with Musca domestica, a study which involved non-fed three-day-old larvae. In the bioassays described in the present study, when eight-day-old larvae were used, they were at a stage of development sufficient to withstand manipulation (withdrawal from development medium and passage to Petri dishes) and they possessed energy reserves sufficient to allow pupation, avoiding an artificial vulnerability to the action of entomopathogenic nematodes.

As performed by Pierce (2012), the current experiments were executed without the activation of photoperiods since, without the protection provided by the development medium, exposure of the larvae to light could become a stressor. Even without light sources, it was common to find larvae searching for shelter between or under the sheets of filter paper in Petri dishes as they exhibit positive geotropism. However, using a 14-hour photoperiod, Mahmoud et al. (2007) found low mortality in the control groups of their study. The same occurred in the present study and research performed for Pierce (2012), indicating that photoperiod does not affect larval viability under these conditions.

\section{Bioassay with S. calcitrans larvae}

The mortality of $S$. calcitrans larvae caused by two days of exposure to $H$. bacteriophora HP88 was $96.7 \%$ in the treatments with the three highest concentrations (100, 150 and 200 EPNs/larva) (Figure 1). After 10 days of exposure, there was a significant difference $(\mathrm{p}<0.05)$ in mortality between all groups treated with EPNs and their respective controls in which high larval viability was observed (Table 1). However, no significant difference $(\mathrm{p}>0.05)$ was observed between groups treated with different concentrations of EPNs of $H$. bacteriophora HP88. This result indicates that, under the conditions in which the study was carried out, this strain was highly virulent for $S$. calcitrans larvae even at relatively low concentrations. With regard to the $H$. baujardi LPP7, the $33.3 \%$ mortality in the group treated with $25 \mathrm{EPN}$ /larva differed significantly $(\mathrm{p}<0.05)$ from treatments with concentrations of 150 and 200 EPNs/larva where mortality rates of $80.0 \%$ and $93.3 \%$ were found. No significant differences ( $p>0.05)$ were observed among the other treated groups (50, 100, 150 and 200 EPNs/larva).

The emergence of adults in the control group for $H$. bacteriophora HP88 reached $80 \%$ of the total available samples representing

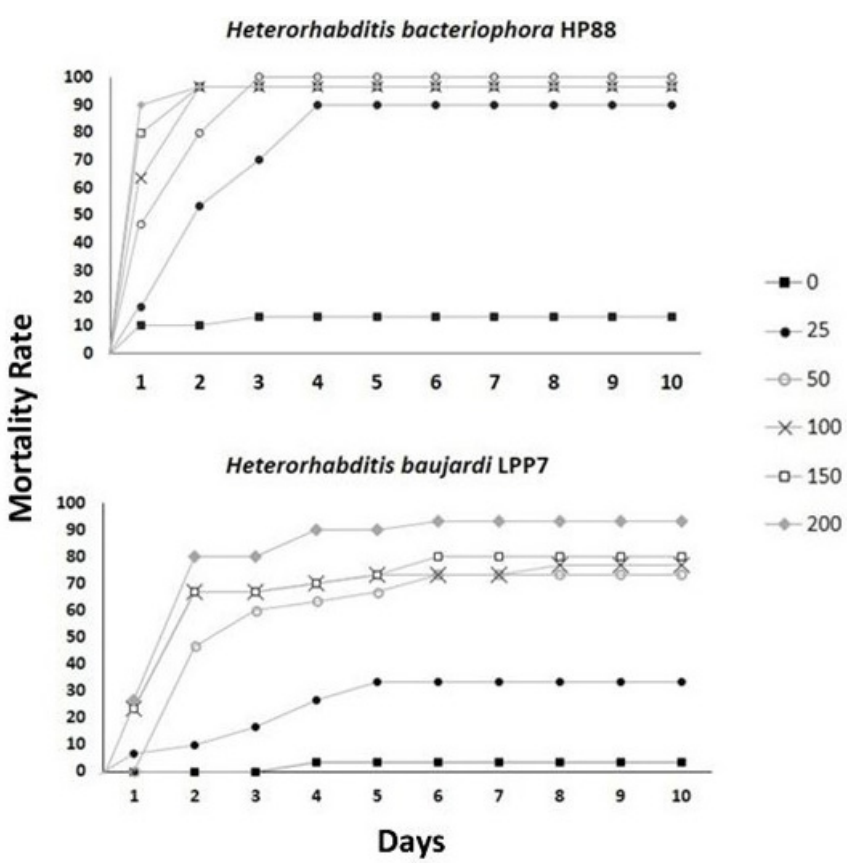

Figure 1. Cumulative mortality of third instar larvae of Stomoxys calcitrans exposed to different concentrations of Heterorhabditis bacteriophora, strain HP88, and Heterorhabditis baujardi, strain LPP7, under laboratory conditions $\left(27 \pm 1^{\circ} \mathrm{C}, 70-80 \% \mathrm{RH}\right)$. 
92.3\% pupal viability. However, in the treated groups, total emergence was highly inhibited. Although the concentrations of 100, 150 and 200 EPN/larva did not achieve 100\% larval mortality, pupae formed in these groups were not viable since there was no emergence of adults after two weeks of observation (Table 2). In the groups treated with $H$. baujardi LPP7, the emergence of adults decreased as the concentration of EPNs increased. The viability of the pupae formed in each group remained high with the exception of the two groups with the highest concentrations (150 and 200 EPNs/larva) (Table 2).

When comparing the results of larval mortality at the same concentrations of the two strains, H. bacteriophora HP88 had higher virulence and led to higher mortality $(\mathrm{p}<0.05)$ than $H$. baujardi LPP7 except at the concentration of 200 EPNs/larvae in which similar results were observed for both species ( $p>0.05)$ (Table 1). Thus, based on virulence tests, $H$. bacteriophora HP88 presents greater potential for control of $S$. calcitrans. This strain has also been identified as possessing the greatest potential for control of the tick Rhipicephalus microplus (MONTEIRO \& PRATA, 2013). In in vivo experiments applying these nematodes in cadaver-insect

Table 1. Mean mortality of larvae of the third instar (eight days old) of Stomoxys calcitrans treated with different concentrations of Heterorhabditis baujardi, strain LPP7, or Heterorhabditis bacteriophora, strain HP88, under laboratory conditions $\left(27 \pm 1^{\circ} \mathrm{C}\right.$ and UR $\left.70-80 \%\right)$ (Mean \pm standard deviation).

\begin{tabular}{ccc}
\hline $\begin{array}{c}\text { EPN/larva } \\
\text { concentrations }\end{array}$ & $\begin{array}{c}\text { Heterorhabditis } \\
\text { bacteriophora } \\
\text { HP88 }\end{array}$ & $\begin{array}{c}\text { Heterorhabditis } \\
\text { baujardi } \\
\text { LPP7 }\end{array}$ \\
\hline 0 (Control) & $13.3^{\mathrm{a}} \pm 10.3$ & $3.3^{\mathrm{a}} \pm 8.1$ \\
25 & $90.0^{\mathrm{bA}} \pm 16.7$ & $33.3^{\mathrm{b}} \pm 32.7$ \\
50 & $100.0^{\mathrm{bA}} \pm 0.0$ & $73.3^{\mathrm{bcB}} \pm 20.7$ \\
100 & $96.7^{\mathrm{bA}} \pm 8.1$ & $76.7^{\mathrm{bcB}} \pm 15.01$ \\
150 & $96.7^{\mathrm{bA}} \pm 8.1$ & $80.0^{\mathrm{cB}} \pm 12.2$ \\
200 & $96.7^{\mathrm{bA}} \pm 8.1$ & $93.3^{\mathrm{cA}} \pm 10.3$ \\
\hline
\end{tabular}

Means followed by different lowercase letters in the same column and by different capital letters on the same line differ statistically at the significance level of $5 \%$.

Table 2. Mean percentages of pupal viability and emergence of Stomoxys calcitrans adults treated at the larval stage with different concentrations of Heterorhabditis baujardi, strain LPP7, or Heterorhabditis bacteriophora, strain HP88, under laboratory conditions $\left(27 \pm 1^{\circ} \mathrm{C}\right.$ and UR 70-80\%).

\begin{tabular}{|c|c|c|c|c|}
\hline Treatments & $\mathbf{n}$ & $\begin{array}{c}\text { EPN/larva } \\
\text { concentrations }\end{array}$ & $\begin{array}{c}\text { Pupal } \\
\text { viability }\end{array}$ & $\begin{array}{c}\text { Adult } \\
\text { emergence }\end{array}$ \\
\hline \multirow{6}{*}{$\begin{array}{l}\text { H. baujardi } \\
\text { LPP7 }\end{array}$} & 30 & 0 (Control) & $93.1 \%$ & $90 \%$ \\
\hline & 30 & 25 & $90 \%$ & $60 \%$ \\
\hline & 30 & 50 & $89 \%$ & $26.7 \%$ \\
\hline & 30 & 100 & $100 \%$ & $23.3 \%$ \\
\hline & 30 & 150 & $59.8 \%$ & $10 \%$ \\
\hline & 30 & 200 & $49.2 \%$ & $3.3 \%$ \\
\hline \multirow{6}{*}{$\begin{array}{c}\text { H. bacteriophora } \\
\text { HP88 }\end{array}$} & 30 & 0 (Control) & $92.3 \%$ & $80 \%$ \\
\hline & 30 & 25 & $33.3 \%$ & $3.3 \%$ \\
\hline & 30 & 50 & $0 \%$ & $0 \%$ \\
\hline & 30 & 100 & $0 \%$ & $0 \%$ \\
\hline & 30 & 150 & $0 \%$ & $0 \%$ \\
\hline & 30 & 200 & $0 \%$ & $0 \%$ \\
\hline
\end{tabular}

formulation, it was also found that $H$. bacteriophora HP88 showed better performance than $H$. baujardi LPP7 (MONTEIRO, 2014). However, such results are contrary to those of Dolinski et al. (2006) who found, using the two strains in tests under laboratory conditions, that $H$. baujardi LPP7 was more virulent for Conotrachelus psidii (Coleoptera: Curculionidae). These results show that the virulence of different species of EPNs varies according to the host, and it is always necessary to carry out specific tests to select the most virulent strains for a particular arthropod species.

In the groups of larvae treated with EPNs of H. bacteriophora HP88, there was no emergence of adults except in the group treated with 25 EPNs/larva (Table 2). This finding shows that, in the present study, infected larvae molted, but most of the pupae formed were not viable. Some authors (e.g., BEAVERS \& CALKINS, 1984; TOLEDO et al., 2005) have reported that it is difficult for EPNs to penetrate through pupal spiracles; however, as the age of the larvae used in the current study was advanced enough for pupation, the molting occurred at the same time as the process of infection by EPNs.

Concentrations of $H$. bacteriophora HP88 yielded an LC50 of 0.36 EPN/larva (0.06-2.45) and LC90 of 29.1 (4.35-195.46) [slope: 0.674]; while $H$. baujardi LPP7 yielded an LC50 of 39.85 (23.45-67.74) and LC90 of 239.18 (140.73-406.5) [slope: 1.647].

Comparing results of this study with others investigating the use of EPNs for the biological control of $S$. calcitrans is a complicated task due to the limited number of such studies. The experiments performed by Mahmoud et al. (2007) involving different species and stages of flies (including S. calcitrans) under similar conditions to the present study show comparable results for third instar larvae. These authors, using the nematode Steinernema feltiae (Cross 33), observed high mortality rates of $S$. calcitrans larvae with concentrations close to those used in the present study $(100 \%$ mortality at concentrations of 80 and $100 \mathrm{EPNs} /$ larva after 72 hours). These results suggest that, in terms of pathogenicity on $S$. calcitrans, the species of Heterorhabditis used in this study offer potential for application as a control method for this dipteran, and require a low number of IJ to reach satisfactory levels of mortality in the laboratory.

Further supporting the use of Heterorhabditis spp. in controlling $S$. calcitrans are the tests performed by Pierce (2012) involving hay/manure. In these tests, both Steinernema spp. and Heterorhabditis spp. were employed and better results were obtained in treatments with the latter. The maximum mortality reached in the present study using $H$. bacteriophora HP88 and $H$. baujardi LPP7 was higher than that observed by Pierce (2012), which was $30.3 \%$. Among all the concentrations used in the present study with the two strains of EPNs, the only one that presented values close to those found by Pierce (2012) was that of 25 EPNs/larva using $H$. baujardi LPP7; the other results were higher.

In their study evaluating the potential of EPNs for control of M. domestica, Geden et al. (1986) found that Heterorhabditis heliothidis (= H. bacteriophora) isolate North Carolina caused mortality close to that invoked by Steinernema feltiae (strain DD-136) on larvae and adults $(27.6 \%$ and $34.8 \%$, respectively, with a concentration of 100 EPNs/larva). Tracing a parallel between S. calcitrans and $M$. domestica, a relevant comparison due to their physiological similarities and phylogenetic proximity, it is notable that a much smaller number of infective juveniles of $H$. bacteriophora was required 
in the present study to cause a high mortality of $S$. calcitrans larvae. Such a finding suggested either greater resistance of $M$. domestica larvae to the action of entomopathogenic nematodes or less virulence of the North Carolina strain when compared to the strain used in the present study.

In contrast, Taylor et al. (1998), who evaluated the pathogenicity of EPNs on larvae of $M$. domestica under experimental conditions similar to those used by Geden et al. (1986), observed that Steinernema spp. were more virulent than Heterorhabditis spp., even mentioning that none of the species of Heterorhabditis used presented potential for control of the domestic fly. From these results, we can infer that strains of the genus Heterorhabditis are not always highly virulent for all flies and that some strains of the genus Steinernema may present greater virulence than certain strains of Heterorhabditis.

\section{Activity over S. calcitrans pupae}

In the test with pupal exposure of $S$. calcitrans to EPNs, high pupal viability was observed in the different treatments regardless of the concentration used. Pupal viability values were 93.3\%, 96.7\% and $96.7 \%$ in the concentrations of 100, 150 and 200 EPNs/pupa, respectively, while in the control, pupal viability was $87.7 \%$. No significant differences were observed between the control and treated groups $(\mathrm{p}>0.05)$. These results are in accordance with the findings of several authors (e.g., BEAVERS \& CALKINS, 1984; TOLEDO et al., 2005) regarding the limited ability of infective juveniles to penetrate pupal spiracles. It is possible that higher concentrations of these EPNs may promote greater mortality, but this aspect requires further investigation.

\section{Retrieval of EPNs from White traps}

The appearance of fly larvae in the groups treated with Heterorhabditis (Figure 2) is in accordance with Kaya \& Gaugler's (1993) description. The dead larvae showed coloration tending

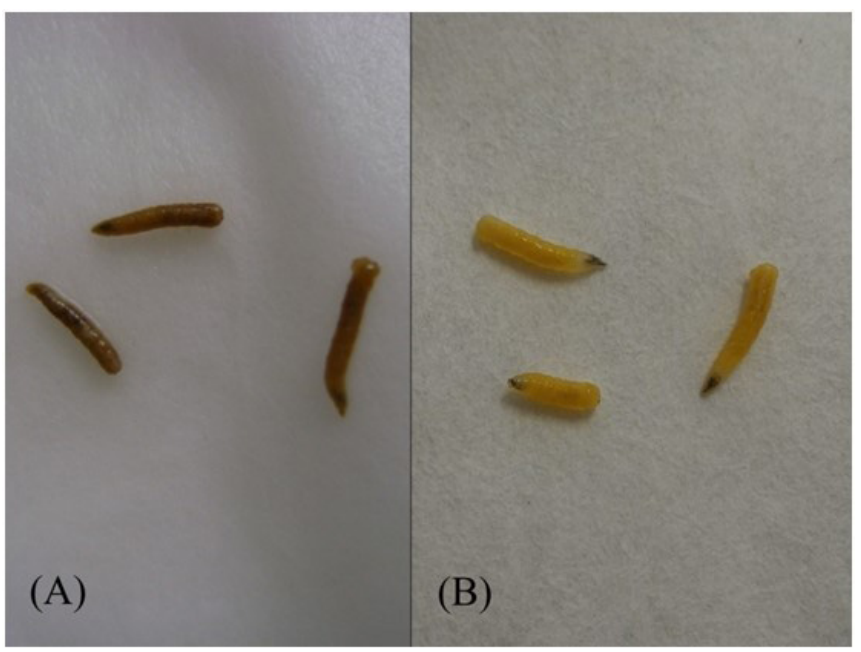

Figure 2. Alteration of color and appearance of Stomoxys calcitrans larvae caused by infection by EPNs of the genus Heterorhabditis. (A) dead larvae after the attack from EPNs; (B) live larvae of the control group. to red/brown after their death and lost the natural glow of the integument, which is related to multiplication of the symbiotic bacteria, proliferation of EPNs and use of the insect as a nutritional source. Two weeks after assembling the White traps, a large number of infective juveniles was found in the water in Petri dishes.

\section{Conclusions}

It was concluded that the Heterorhabditis bacteriophora HP88 and Heterorhabditis baujardi LPP7 showed pathogenicity to $S$. calcitrans larvae under laboratory conditions and were able to cause a high mortality; H. bacteriophora HP88 was the most virulent strain. However, pupae of $S$. calcitrans were resistant to infection by infective juveniles of these nematodes.

Despite this study being strictly under laboratory conditions, the finding of lower efficiency of $H$. baujardi LPP7, compared to $H$. bacteriophora HP88, in the control of $S$. calcitrans should not be a reason for discontinuation of bioassays involving that strain given that the efficacy levels demonstrated by both species are considerably high in terms of biological control, especially considering the concentrations used. The efficacy of Heterorhabditis baujardi LPP7 appears to be dose-dependent, and this isolate also has some positive characteristics for its applicability in Brazil: it is a native EPN collected in the Amazon region (DOLINSKI et al., 2008) and is adapted to the weather conditions of a tropical country.

\section{References}

Baldacchino F, Muenworn V, Desquesnes M, Desoli F, Charoenviriyaphap T, Duvallet G. Transmission of pathogens by Stomoxys flies (Diptera, Muscidae): a review. Parasite 2013; 20: 26. PMid:23985165. http:// dx.doi.org/10.1051/parasite/2013026.

Beavers JB, Calkins CO. Susceptibility of Anastrepha suspensa (Diptera: Tephritidae) to steinernematid and heterorhabditid nematodes in laboratory studies. Environ Entomol 1984; 13(1): 137-139. http://dx.doi. org/10.1093/ee/13.1.137.

Bittencourt AJ. Avaliação de surtos e medidas de controle ambiental de Stomoxys calcitrans (Diptera: Muscidae) na Região Sudeste do Brasil. Rev Bras Med Vet 2012; 34(S1): 73-82.

Boemare NE, Akhurst RJ, Mourant RG. DNA relatedness between Xenorhabdusspp. (Enterobacteriaceae), symbiotic bacteria of entomopathogenic nematodes, and a proposal to transfer Xenorhabdus luminescens to a new genus, Photorhabdus gen. nov. Int J Syst Bacteriol 1993; 43(2): 249-255. http://dx.doi.org/10.1099/00207713-43-2-249.

Campbell JB, Berry IL, Boxler DJ, Davis RL, Clanton DC, Deutscher GH. Effects of stable flies (Diptera: Muscidae) on weight gain and feed efficiency of feedlot cattle. J Econ Entomol 1987; 80(1): 117-119. PMid:3571695. http://dx.doi.org/10.1093/jee/80.1.117.

Christmas PE. Laboratory rearing of the biting fly Stomoxys calcitrans (Diptera: Muscidae). NZ Entomol 1970; 4(4): 45-49. http://dx.doi.org /10.1080/00779962.1970.9723073.

Cook DF, Dadour IR, Keals NJ. Stable fly, house fly (Diptera: Muscidae), and other nuisance fly development in poultry litter associated with horticultural crop production. J Econ Entomol 1999; 92(6): 1352-1357. PMid:10633577. http://dx.doi.org/10.1093/jee/92.6.1352. 
Dolinski C, Kamitani FL, Machado IR, Winter CE. Molecular and morphological characterization of heterorhabditid entomopathogenic nematodes from the tropical rainforest in Brazil. Mem Inst Oswaldo Cruz 2008; 103(2): 150-159. PMid:18425267. http://dx.doi.org/10.1590/ S0074-02762008000200005.

Dolinski CM, Valle EE, Stuart RJ. Virulence of entomopathogenic nematodes to larvae of the guava weevil, Conotrachelus psidii (Coleoptera: Curculionidae) in laboratory and greenhouse experiments. Biol Control 2006; 38(3): 422-427. http://dx.doi.org/10.1016/j.biocontrol.2005.12.014.

Finney DJ. Probit analysis: a statistical tratment of the sigmoid response curve. 2nd ed. Cambridge: University Press; 1952.

Furman DP, Catts EP. Manual of medical entomology. 4th ed. Cambridge: University Press; 1982.

Geden CJ, Axtell RC, Brooks WM. Susceptibility of the house fly, Musca domestica (Diptera: Muscidae), to the entomogenous nematodes Steinernema feltiae, S. glaseri (Steinernematidae), and Heterorhabditis heliothidis (Heterorhabditidae). J Med Entomol 1986; 23(3): 326-332. PMid:3735337. http://dx.doi.org/10.1093/jmedent/23.3.326.

Georgis R, Manweiler SA. Entomopathogenic nematodes: a developing biological control technology. Agric Zool Rev 1994; 6: 63-94.

Grisi L, Leite RC, Martins JR, Barros ATM, Andreotti R, Cançado $\mathrm{PHD}$, et al. Reassessment of the potential economic impact of cattle parasites in Brazil. Rev Bras Parasitol Vet 2014; 23(2): 150-156. PMid:25054492. http://dx.doi.org/10.1590/S1984-29612014042.

Hazir S, Kaya HK, Stock P, Keskin N. Entomopathogenic nematodes (Steinernematidae and Heterorhabditidae) for biological control of soil pests. Turk J Biol 2003; 27: 181-202.

Kaya HK, Gaugler R. Entomopathogenic nematodes. Annu Rev Entomol 1993; 38(1): 181-206. http://dx.doi.org/10.1146/annurev. en.38.010193.001145.

Mahmoud MF, Mandour NS, Pomazkov YI. Efficacy of the entomopathogenic nematode Steinernema feltiae Cross N 33 against larvae and pupae of four fly species in the laboratory. Nematol Mediterr 2007; 35(2): 221-226.

Mello RP. Estudo de alguns aspectos do desenvolvimento biológico e do comportamento, em laboratório, de Stomoxys calcitrans (Linnaeus, 1758) (Diptera: Muscidae) [dissertation]. Seropédica: Universidade Federal Rural do Rio de Janeiro; 1989.

Monteiro CMO, Prata MCA, Furlong J, Fazza AP, Mendes AS, Andaló $\mathrm{V}$, et al. Heterorhabditis amazonensis (Rhabditidae: Heterorhabditidae), strain RSC-5, for biological control of the cattle tick Rhipicephalus (Boophilus) microplus (Acari: Ixodidae). Parasitol Res 2010; 106(4): 821826. PMid:20127363. http://dx.doi.org/10.1007/s00436-010-1720-6.
Monteiro CMO, Prata MCA. Controle biológico do carrapato dos bovinos Rhipicephalus microplus com a utilização de nematoides entomopatogênicos: conquistas e desafios. In: Veríssimo CJ, editor. Controle de carrapatos nas pastagens. Nova Odessa: Instituto de Zootecnia; 2013. p. 46-68.

Monteiro CMO. Controle de Rhipicephalus microplus (Acari: Ixodidae) com nematoides entomopatogênicos: aplicação em formulação inseto cadáver e compatibilidade com outros agentes de controle [dissertation]. Seropédica: Universidade Federal Rural do Rio de Janeiro; 2014.

Moraes APR. Stomoxys calcitrans: estabelecimento de colônia e efeito de Metarhizium anisopliae sobre seus estágios imaturos [dissertation]. Seropédica: Universidade Federal Rural do Rio de Janeiro; 2007.

Pierce LR. Efficacy of entomopathogenic nematodes utilized for control of stable flies (Stomoxys calcitrans) at round bale feeding sites [dissertation]. Stillwater: Oklahoma State University; 2012.

Samish M, Ginsberg H, Glazer I. Anti-tick biological control agents: assessment and future perspectives. In: Bowman AS, Nuttall PA, editors. Ticks: biology, disease and control. Cambridge: University Press; 2008. p. $447-469$.

Senna-Nunes M, Costa GL, Bittencourt VREP, Souza EJ. Avaliaçấo in vitro dos fungos Aspergillus flavus e Penicillium corylophylum em larvas de Musca domestica (Diptera: Muscidae). Parasitol Latinoam 2002; 57(34): 134-140. http://dx.doi.org/10.4067/S0717-77122002000300009.

Silva ER, Monteiro CMO, Reis-Menini C, Prata MCA, Dolinski C, Furlong J. Action of Heterorhabditis indica (Rhabditida: Heterorhabditidae) strain LPP1 on the reproductive biology of engorged females of Rhipicephalus microplus (Acari: Ixodidae). Biol Control 2012; 62(3): 140-143. http:// dx.doi.org/10.1016/j.biocontrol.2012.05.007.

Taylor DB, Moon RD, Mark DR. Economic impact of stable flies (Diptera: Muscidae) on dairy and beef cattle production. J Med Entomol 2012; 49(1): 198-209. PMid:22308789. http://dx.doi.org/10.1603/ME10050.

Taylor DB, Szalanski AL, Adams BJ, Peterson RD 2nd. Susceptibility of house fly (Diptera: Muscidae) larvae to entomopathogenic nematodes (Rhabditida: Heterorhabditidae, Steinernematidae). Environ Entomol 1998; 27(6): 1514-1519. http://dx.doi.org/10.1093/ee/27.6.1514.

Toledo J, Ibarra JE, Liedo P, Gómez A, Rasgado MA, Williams T. Infection of Anastrepha ludens (Diptera: Tephritidae) larvae by Heterorhabditis bacteriophora (Rhabditida: Heterorhabditidae) under laboratory and field conditions. Biocontrol Sci Technol 2005; 15(6): 627-634. http://dx.doi. org/10.1080/09583150500089049.

White GF. A method for obtaining infective nematode larvae from cultures. Science 1927; 66(1709): 302-303. PMid:17749713. 